\title{
Les aménagements hydroélectriques de la province de Québec
} Hydroelectric development
in the province of Quebec

\author{
PAR G. LE MOIGNE \\ INGENIEUT E.T.P. PARIS \\ MASTER OF SCIENCE, CORNELL UNIVERSTTY
}

\begin{abstract}
Le développement des industries du bois, du papier et des métaux non ferreux explique la production particulièrement élevé d'énergie électrique de la Province de Québec où se trouve le noyau principal des Canadiens francais. L'énorme potentiel hydroélectrique de 26.000 .000 ch est dh atu relief abec ses innombrables chutes d'eau, a unte précipitation exceptionnellement bien répartie au cours de l'année et à lune politique de conservation des eaux particulierement bien comprise. Les $2,5 \mathrm{~m}$ de neige tombant durant les mois d'hiver et la rétention des eaux a la suite de ce phénomène causent un problème qui a élo résolu grace à la création de réservoirs. La répartition du potentiel hydroélectrique au voisinage des centres industriels et miniers semble providentielle. La mise en valeur des riches ressources minérales de la Gaspésie, région la moins favorisée en potentiel hydroélectrique, a été récemment rendue possible par l'installation de 4 cábles sous-marins de 69.000 volts mesurant chacun $54 \mathrm{~km}$ et ayant une capacite de $75.000 \mathrm{~kW}$. Les aménagements hydroélectriques de la Province progressent à un rythme remarquable: une moyenne de $320.000 \mathrm{ch}$ par an a été installée au cours des cinq dernières années. Deux importantes réalisations en cours d'achèvement sont décrites dans le présent article: Beauharnois sur la rivière SaintLaurent avec une puissance de $2.500 .000 \mathrm{ch}$ et Bersimis, à $500 \mathrm{~km}$ de Québec, avec une puissance de $2.000 .000 \mathrm{ch}$.
\end{abstract}

\section{I. - INTRODUCTION}

A l'occasion de la commémoration, en 1963, du bi-centenaire du Traité de Paris, par lequel la Nouvelle-France passait à l'Angleterre, on exaltera le miracle de la survivance française au Canada et le rôle important joué par les descendants des 65.000 Français de 1763. De nombreu-

\begin{abstract}
The great energy requirements of the nonferrous metal and of the wood and paper indus. tries account for the exceptionally high production of electricity in the Province of Quebec where live the major part of the French-Canadians. The impressive water-power potential of $26,000,000 \mathrm{hp}$ is due to the "Canadian Shield" with its innumeroble water falls, to the large natural and artificial reservoirs which help gathering and regulating the water brought b! the 100 inches of snow which fall over the watershed during the winter, to a precipitation eaceptionnaly well distributed and to a particularly well suited policy of water conservation. The distribution of the commercial water-power potential near the industrial and mining centers seems providential. The development of the rich mineral ressources of the Gaspé Peninsula, less favored as far as waterpower is concerned, has been made possible with the installation of four 69,000 volts submarine cables having a lenglh of 34 miles and a capacity of $75,000 \mathrm{~kW}$. The harnessing of water-power is progressing at a remarkable speed: the hydraulic turbine installation in the last five years grew at an average yearly rate of $320,000 \mathrm{hp}$. A description is given of two important projects now being completed: Beauharnois on the St. Lawrence River with a capacity of $2,150,000 \mathrm{hp}$, and Bersimis, 300 miles North of Quebec City, with a capacity of $2,000,000 \mathrm{hp}$.
\end{abstract}

\section{I. - INTRODUCTION}

The celebration, in 1963 , of the two century old Treaty of Paris by which "NouvelleFrance" was surrendered to England, will be the occasion for glorifying the miracle of the French survival in Canada and the important part played by the descendants of the 65,000 

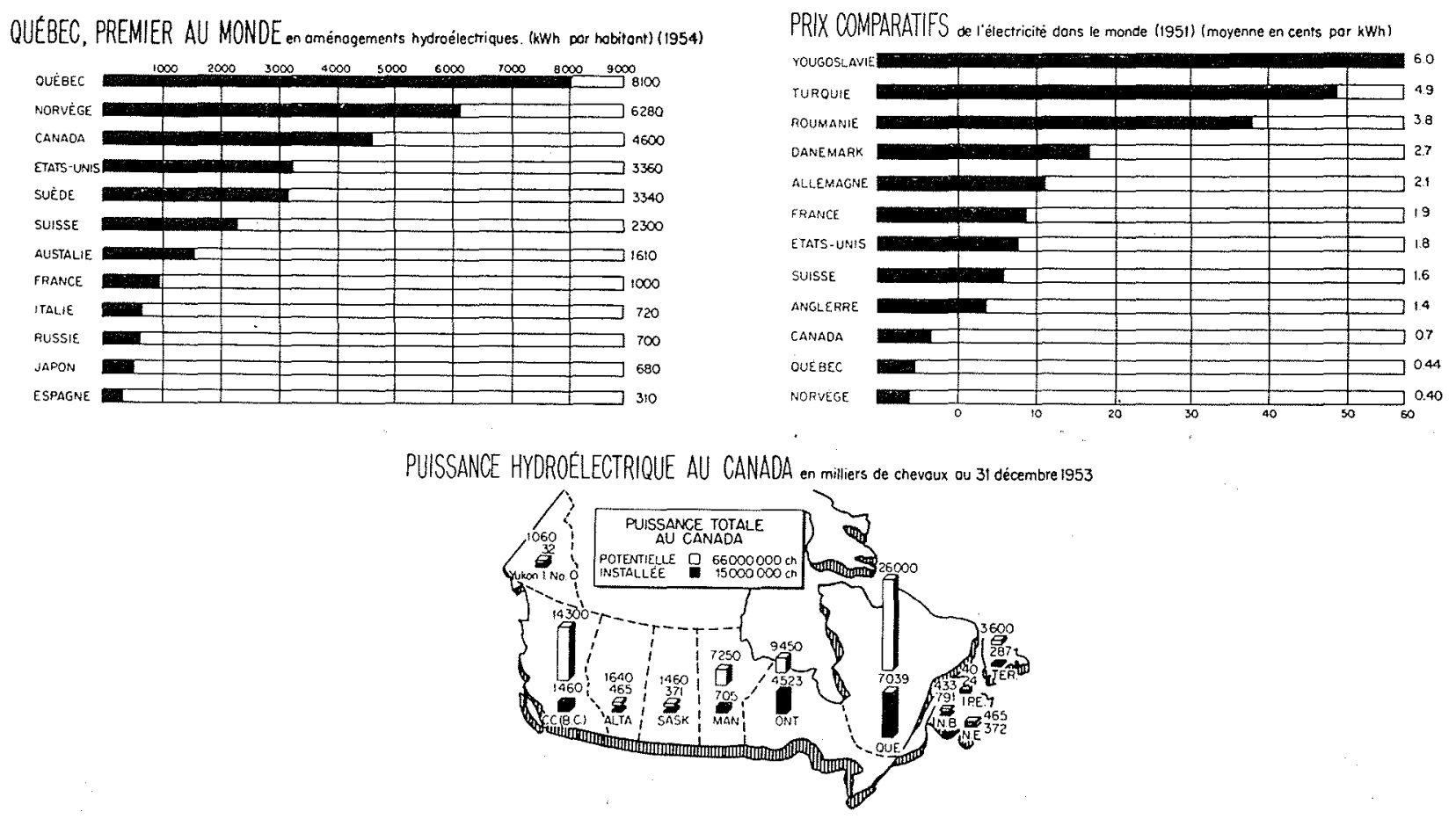

Fr. 1

ses études seront alors soumises sur les progrès accomplïs durant celle période et sur l'influence bienfaisante des deux cultures, française et anglo-saxonne, sur l'économie canadienne. On ne manquera pas d'observer que la mise en valeur des ressources hydroélectriques a joué, et joue encore, un rôle essentiel pour le développement industriel de la province de Québec où se trouve le noyau principal des Canadiens français.

Parmi les nations productrices d'énergie électrique, le Canada, avec 71 milliards de $\mathrm{kWh}$ produits en 1953, occupe le troisième rang après les Etats-Unis (514 milliards de $\mathrm{kWh}$ ) et l'U.R.S.S. (130 milliards de kWh). La Province de Québec vient sans contredit en tête de tout le Canada (voir fig. 1) et les $8.200 \mathrm{kWh}$ per capita produits au Québec dépassent les $5.700 \mathrm{kWh}$ de la Norvège et sont plus du double des $3.200 \mathrm{kWh}$ des Etats-Unis. Le Royaume-Uni n'en produit que 1.300, la France 900 et l'U.R.S.S. 650.

\section{II. - LES RESSOURCES}

\section{HYDROELECTRIQUES DE LA PROVINCE}

Le Québec est bien en tête des autres régions canadiennes en ce qui concerne ses ressources en houille blanche (fig. 1). Le potentiel disponible de 26000000 de ch représente environ $40 \%$ du potentiel canadien. Cet énorme potentiel est
French of 1763 . Then, there will be submilted many studies on the progress achieved during this period, and on the beneficial influence of the French and Anglo-Saxon cultures on the Canadian economy. One shall not fail to notice that the harnessing of hydroelectric power has played-and continues to play-an essential part in the industrial development of the Province of Quebec where live the major part of the French Canadians.

Among the nations producing electric energy, Canada, with 71 billions $\mathrm{k}$ Wh produced in 1953 , ranks third after the United States (514 billions $\mathrm{kWh}$ ) and the USSR ( 130 billions $\mathrm{kWh}$ ). Within Canada itself the Province of Quebec is by far the leader (see Figure 1), and the $8,200 \mathrm{kWh}$ per capita produced in Quebec are more than the $5,700 \mathrm{kWh}$ of Norway and the $3,200 \mathrm{kWh}$ of the United States. The United Kingdom produces only 1,300 kWh per capita, France, $900 \mathrm{kWh}$ and the USSR, $650 \mathrm{kWh}$.

\section{II. - HYDROELECTRIC RESOURCES OF THE PROVINCE OF QUEBEC}

The Province of Quebec has the greatest potential water power of the Provinces of Canada (see Figure 1). The $26,000,000 \mathrm{hp}$ available represent approximately 40 p.c. of the water power resources of Canada. This impressive potentiality is 


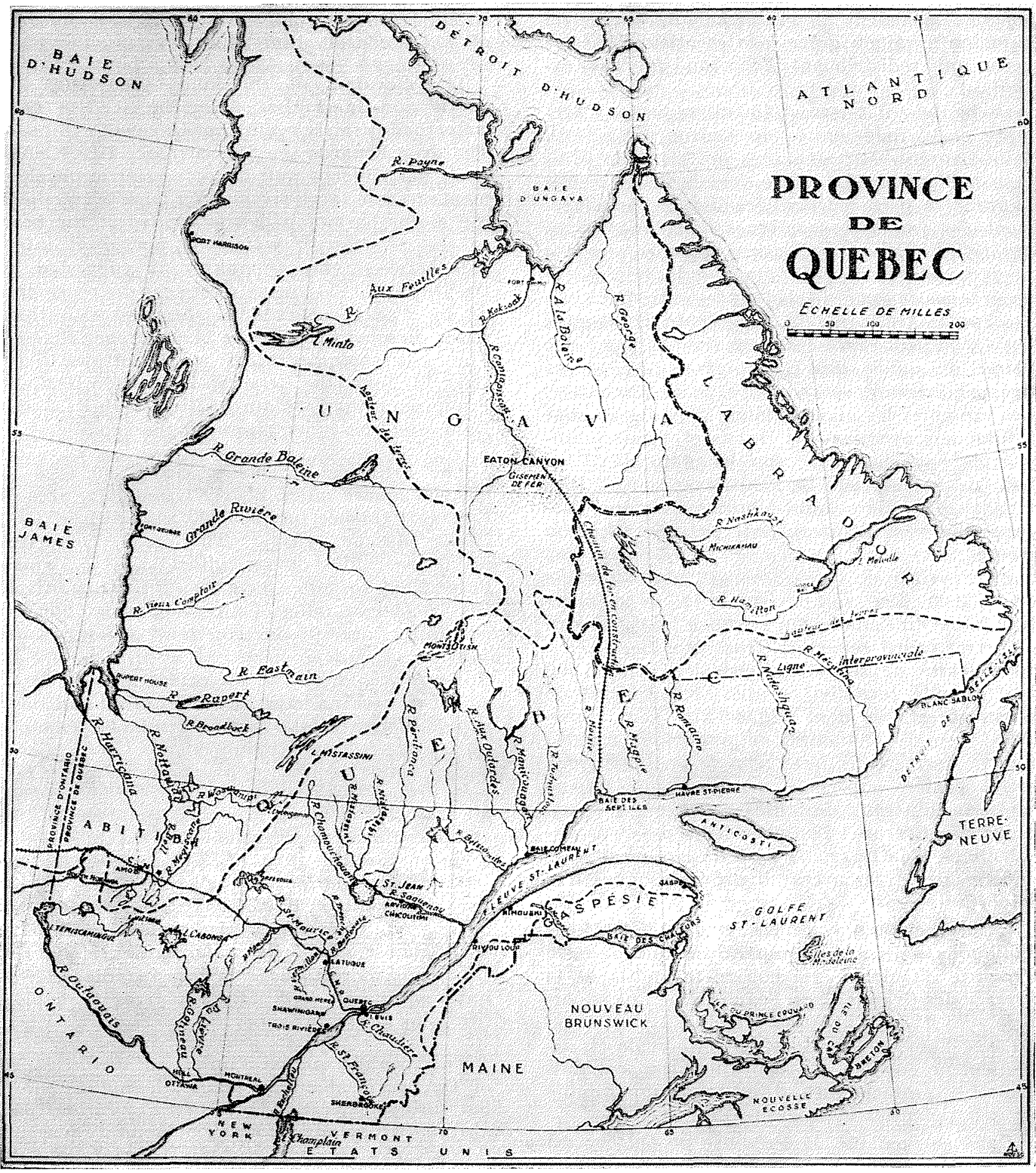

FIG. 2

dû au relief avec ses innombrables chutes d'eau, à une précipitation exceptionnellement bien répartie au cours de l'année et à une politique de conservation des eaux particulièrement bien comprise. La neige tombant durant les mois d'hiver et la rétention des eaux à la suite de ce due to the "Canadian Shield" with its innumerable water falls; to the large natural and artificial reservoir which help gathering and regulating the water brought by the 100 inches of snow which fall over the watershed during the winter; to a precipitation exceptionally well dis- 
phénomène, créent un problème que l'industrie humaine a vaincu grâce à la création de réservoirs qui redistribuent l'eau au gré des exploitants.

La hauteur des terres $(460 \mathrm{~m})$ séparant l'Arctique et la Baie James du bassin versant du Saint-Laurent est à peu près uniforme de l'Ungava à l'Ontario. La chute vers le fleuve SaintLaurent se prête particulièrement à l'aménagement des forces hydrauliques: quelques grandes rivières à vastes bassins versants, dont la plus grande partie est située à la tête de la rivière, avec cascades échelonnées entre des rives escarpées. Ainsi que le suggère le $D^{r}$ Dupuis (1954), on peut représenter ces rivières par «des poires ou même des champignons avec leurs tiges se dirigeant vers le fleuve Saint-Laurent ». Les exemples les mieux connus (voir fig. 2) sont l'Outaouais avec ses lacs Dozois et Temiscamingue; le Saguenay avec son lac naturel, le lac Saint-Jean; la rivière Bersimis, avec son lac Pipmuacan, la rivière Saint-Maurice avec son barrage Gouin et d'autres rivières encore sur la même rive.

La Province de Québec couvre une superficie de $1.520 .000 \mathrm{~km}^{2}$, soit environ le $1 / 6$ de la superficie totale du Canada. On y trouve $1.335 .000 \mathrm{~km}^{2}$ de terres, ainsi réparties (Huet Massue, 1954) : $165.000 \mathrm{~km}^{2}$ de superficie agricole, dont 66.500 $\mathrm{km}^{2}$ ont été jusqu'ici occupés; $820.000 \mathrm{~km}^{2}$ de terres forestières dont $520.000 \mathrm{~km}^{2}$ sont considérés comme productifs; enfin quelque 350.000 $\mathrm{km}^{2}$ de terres considérés comme incultes. Dans cette dernière superficie, des gisements importants de minéraux de toutes sortes ont été jusqu'ici découverts et l'on prévoit qu'il s'en découvrira bien d'autres, dans un territoire où il reste encore des ressources hydroélectriques très importantes.

L'eau occupe une superficie de $185.000 \mathrm{~km}^{2}$. Indiquons à titre de comparaison que dans la Province d'Ontario, qui couvre la moitié de la surface des Grands Lacs, l'eau occupe une superficie de $125.000 \mathrm{~km}^{2}$ seulement. II est vrai qu'avec l'aménagement de 1,1 million de ch actuellement en voie de réalisation sur le SaintLaurent, l'Ontario aura utilisé la presque totalité de son potentiel hydroélectrique.

Dans ce domaine, la Province de Québec est plus favorisée. La précipitation annuelle sur la Province est en moyenne de $1,0 \mathrm{~m}$ d'eau (Lawton, 1947). La précipitation mensuelle varie entre $9,5 \mathrm{~cm}$ en janvier et juillet et $6,6 \mathrm{~cm}$ en avril (Huet Massue, 1956).

Le ruissellement annuel moyen des rivières de la Province est d'environ 17 litres par seconde par $\mathrm{km}^{2}$ de bassin versant. Le ruissellement maximum varie de 70 à 100 litres par seconde par $\mathrm{km}^{2}$ de bassin versant, tandis que le ruissel- tributed and to a particularly well suited policy of water conservation (Huet Massue, 1956).

The elevation of the lands separating the Arctic and James Bay from the St. Lawrence watershed is fairly even from Ungava to Ontario. The drop towards the St. Lawrence River lends itself particularly well to hydroelectric developments : some large rivers with large watersheds the major part of which is located at the head of the river, with waterfalls placed at intervals between abrupt banks. As suggested by Dr. Dupuis (1954) these rivers can be represented by "pears or even mushrooms with their stems directed towards the St. Lawrence River." The most famous examples are the Ottawa River, Lake St. John, the Bersimis River with its Lake Pipmuacan, the St. Maurice River with its Gouin Dam, and also other rivers on the same bank.

The Province of Quebec covers an area of 600,000 square miles, nearly 1,6 of total area of Canada. Quebec has 525,000 sq. miles of land (Huet Massue, 1954). This land comprises $65,000 \mathrm{sq}$. miles of agricultural area of which only $26,000 \mathrm{sq}$. miles have been hitherto cultivated; 320,000 sq. miles of forests of which 200,000 sq. miles are productive; and finally some $140,000 \mathrm{sq}$. miles considered as wild land. In this last area, however, important mineral deposits of every kind have been discovered and their exploitation will take advantage of a large potential of hydroelectric resources.

In the whole Province of Quebec, water covers an area of $75,000 \mathrm{sq}$. miles. It is interesting to compare this area with the $64,000 \mathrm{sq}$. mile water area of the Province of Ontario which contains half the surface of the Great Lakes. With the equipment of $1,100,000 \mathrm{HP}$ now under way on the St. Lawrence River, Ontario will have used almost all of its water power resources. Quebec is more favored in this regard and will have additional hydraulic resources to exploit for some years to come.

The average annual rainfall in the Province of Quebec is about 36 inches, including snow, but varies moderately according to locations and altitudes (Lawton, 1947). The monthly precipitation varies between $9.5 \mathrm{~cm}$ in January and July and $6.6 \mathrm{~cm}$ in April (Huet Massue, 1956).

The average yearly run-off is about 1.6 cubic feet per second per sq. mile of drainage area. The maximum run-off varies between 6 and 10 cubic feet per second per sq. mile of drainage area whereas the minimum run-off varies between 0.25 and 0.40 cubic feet.

Storage is therefore essential to optimum 
lement minimum varie de 3 à 4 litres. On concoit aisément que la création de réservoirs soit essentielle au développement des ressources hydroélectriques des rivières de la Province, à l'exception toutefois du Saint-Laurent dont le débit, remarquablement uniforme (le rapport de son débit maximum à son débit minimum est de deux), est dû au réservoir naturel constitué par les Grands Lacs.

Les réservoirs de la Province de Québec contiennent quelque 41,5 milliards de $\mathrm{m}^{*}$ d'eau. Ces réservoirs aident à recueillir au printemps la fonte des $2,5 \mathrm{~m}$ de neige qui tombent sur les bassins versants durant les mois d'hiver. Les avantages offerts par ces réservoirs sont appréciables: sur la seule rivière Saint-Maurice par exemple, le lac artificiel Gouin a transformé le potentiel de la rivière de $700.000 \mathrm{ch}$ à environ $2.500 .000 \mathrm{ch}$ (Heartz, 1951). Ces réservoirs permettent d'expliquer le prix de revient exceptionnellement bas du $\mathrm{kWh}$ dans la Province de Québec (voir fig. 1).

La répartition du potentiel commercial des 26.600.000 ch de la Province présente beaucoup d'intérêt (voir fig. 3).

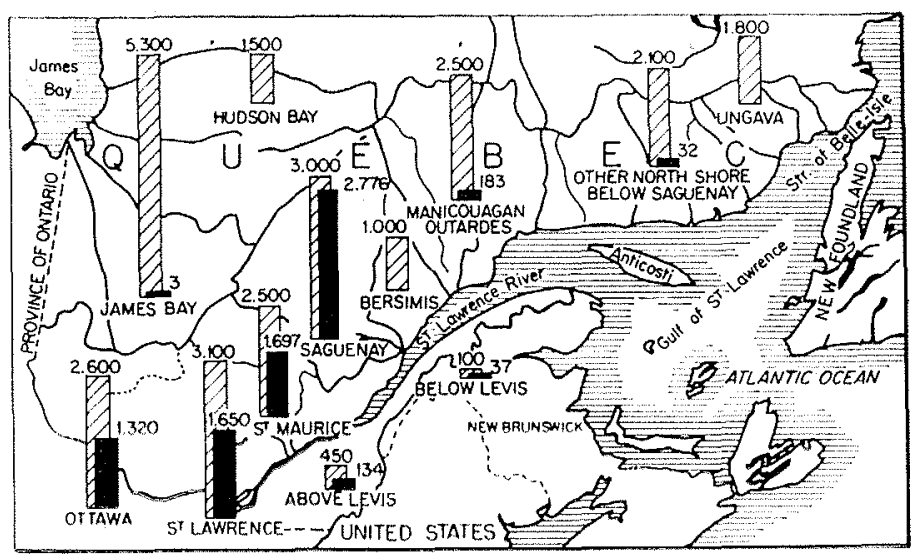

Ainsi que l'observe le $\mathrm{D}^{r}$ Dupuis (1951), cette puissance se retrouve un peu en « paquets »: un paquet de 3,1 millions de ch aux environs directs de Montréal : Beauharnois et Lachine; un paquet de 2,6 millions de ch à louest assez rapproché de Montríal : les bas de la rivière Outaouais, la rivière Gatineat et la Lièvre; un paquet de 2,5 millions de ch sur la Saint-Maurice; un paquet de 3 millions de ch au lac Saint-Jean, de 2 millions de ch sur la rivière Bersimis et de 2,5 millions de ch sur les rivières Manicouagan et Aux Outardes; un paquet malheureusement peu important sur la rive sud du Saint-Laurent; un paquet de 3,9 millions de ch sur la côte nord; quelque 5,3 millions de ch près de la Baie James.

Cette distribution est tout à fait remarquable : elle semble providentielle. Le district de development of practically all water powers in Quebec, with the exception of the St. Lawrence River which is endorsed with a remarkably uniform flow due to the great natural storage of the Great Lakes. In Quebec, storage reservoirs contain 4,150 billion cubic feet of water. These reservoirs help to gather in the Spring the water from the 100 inches of snow which normally fall over the entire watershed during the Winter months. The benefits derived from these storages are quite noticeable; on the St. Maurice River alone, for example, it is estimated that it has transformed the potential of the river from about $700,000 \mathrm{HP}$, under natural conditions, to about 2,500,000 HP under present regulation. Were it not for these storage reservoirs, the extraordinary low cost of the kWh (see Figure 1) would never be possible.

The distribution of the commercial potential of $26,600,000 \mathrm{HP}$ of the Province of Quebec is particularly interesting. As observed by Dr. Dupuis (1951), "The water power resources are grouped by "packs": a pack of 3,1 millions HP in the immediate vicinity of Mont-

Fig. 3

Energie hydraulique du Québec, en milliers de ch, au 31 décembre 1955. (Potentiel commercial : $26.600 .000 \mathrm{ch}$. Installations : $7.975 .657 \mathrm{ch}$.)

Quebec's water power. Thousand horsepower, december 31, 1955. (Commercial potential: 26,600,000 HP. Installation: $7,975,657 \mathrm{KP}$.)

real : Beauharnois and Lachine; a pack of 2.6 millions HP West of Montreal : the downstream part of the Ottawa, Gatineau and La Lievre Rivers; a pack of 2.5 millions HP on the St. Maurice River; a pack of 3 millions HP near Lake St. John, of 2 millions $H P$ on the Bersimis River, and of 2.5 millions HP on the Manicuagan and Aux Outardes Rivers; a small pack on the south bank of the St. Lawrence River; a pack of 3.9 millions HP on the North coast, and finally some 5.3 millions $H P$ near James Bay.'

This distribution seems providential. The district of Montreal towards Ottawa has a potential of 5,7 millions HP which are highly useful for the industrial development of this area. The 
Montréal, en allant vers Ottawa, possède donc 5,7 millions de ch, ce qui est très intéressant pour l'industrie en général et les papeteries de la Gatineau et de la Lièvre en particulier. Dans le district des Trois-Rivières, où il $\mathrm{y}$ de nombreuses papeteries, on trouve 2,5 millions de ch, qui sont aussi très utiles pour le développement minier. Dans les rivières qui se déversent soit vers l'océan Arctique ou dans le SaintLaurent, dans la région minière du Nord-Ouest, Rouyn-Noranda, on trouvera la puissance nécessaire aux usines de l'Abitibi. C'est la rivière sud et surtout la Gaspésie (très riche en ressources minières) qui sont le moins bien partagées en ressources hydroélectriques. Il y a là tout un problème qui a été récemment résolu (1954) grâce à quatre câbles immergés de 69.000 volts mesurant chacun $54 \mathrm{~km}$ et d'une puissance de transport de $75.000 \mathrm{~kW}$; ces câbles relient la péninsule de Manicouagan, sur la côte nord, et les Boules, sur la côte de Gaspé. L'instaltation de ces câbles représente une initiative hardie, dont peut se glorifier, à juste titre, la Commission hydroélectrique de la Province de Québec.

\section{III. - LES AMÉNAGEMENTS HYDROELECTRIQUES DE LA PROVINCE}

La vente d'énergie électrique ver's l'Ontario, le développement des industries du bois, du papier et des métaux non ferreux expliquent la production particulièrement élevée d'énergie électrique de la Province.

Les aménagements progressent à un rythme remarquable : 1 million de ch en 1920 , 3 millions de ch en 1930, 5 millions de ch en 1940, 6 millions de ch en 1950 et 8,5 millions de ch à la fin de l'année 1956. Au rythme annuel de $320.000 \mathrm{ch}$ auquel les forces hydrauliques du Québec ont été aménagées durant les cing dernières années ( $510.000 \mathrm{ch}$ en 1956), l'aménagement que l'on est en train de poursuivre à Bersimis (voir section $V$ ) devrait être absorbé d'ici 1960 ou 1962. Environ les deux tiers du potentiel électrique du centre de la Province auront été alors mis en ouvre. Les 1,2 million de ch des rapides de Lachine, $750.000 \mathrm{ch}$ supplémentaires de Beauharnois, $400.000 \mathrm{ch}$ de Carillon et les quelques $750.000 \mathrm{ch}$ à la tête du Saint-Maurice constituent les sources additionnelles les plus importantes de houille blanche de la région de Montréal, centre actuel de la plus grande activité.

Le Québec manque totalement de ressources en charbon et, par suite, les centrales thermiques ne pourraient fournir de l'électricité qu'à des prix prohibitifs. Par ailleurs, nous ne voyons rien
2.5 millions HP near the district of Trois-Rivieres are used mainly by the wood and paper industries and the mining industries. The power necessary for the development of the non-metallic mineral region of the North West, will be found in the rivers discharging into the Arctic Ocean or the St. Lawrence River. The less favored regions, as far as water power is concerned, are the South bank of the St. Lawrence River and especially the Gaspe Peninsula very rich in mineral resources. The development of these regions created therefore a problem which was solved recently (1954), with the installation of four 69,000 volt submarine cables having a length of 34 miles and a capacity of $75,000 \mathrm{~kW}$. These cables connect the Manicuagan Peninsula on the North coast and "les Boules" on the shore of Gaspe. This installation is an accomplishment the Quebec Hydroelectric Commission can be justly proud of.

\section{III - HYDROELECTRIC DEVELOPMENT IN QUEBEC}

The great energy requirements of the nonferrous metal and of the wood and paper industries account for the exceptionally high production of electricity in Quebec (Huet Massue, 1956).

The harnessing of water power is progressing at a remarkable speed : 1 million $H P$ in 1920 , 3 millions HP in 1930, 5 millions $H P$ in 1940 , 6 millions $\mathrm{HP}$ in 1950 , and 8.5 millions $\mathrm{HP}$ at the end of the year 1956 . The hydraulic turbine installation in the last five years, grew at an average yearly rate of $320,000 \mathrm{HP} \quad(510,000 . \mathrm{HP}$ in 1956). At that rate, the present development on the Bersimis River (See Section V) should be absorbed in 1960 or 1962 . Two-thirds of the commercial potential of the centre part of the Province will have then been developed. The 1.2 million HP available at the Lachine rapids on the St. Lawrence River near Montreal, the $750,000 \mathrm{HP}$ at Beauharnois, $400,000 \mathrm{HP}$ at Carillon and some $750,000 \mathrm{HP}$ at the head of the St. Maurice River represent the most important additional water power resources of the Montreal area where the greatest industrial activity is now located.

Quebec has no carboniferous resources and therefore power obtained from thermal plants would be extremely expensive. On the other hand, we do not believe that in the near future, 
actuellement, ou dans un avenir rapproché, qui permette d'espérer que l'énergie atomique puisse concurrencer économiquement l'énergie hydraulique, même très éloignée des centres de consommation. Il est donc hautement probable que les rivières de la côte nord et celles près de la baie James seront aménagées dans un futur très rapproché, d'autant plus que ces rivières sont situées près de centres miniers très importants. Certes, toutes ces rivières sont bien loin de Montréal, mais leur aménagement peut être particulièrement économique et Bersimis en est un exemple frappant. La conformation des bassins versants, qu'on peut facilement agrandir en acquérant des terrains ni cultivés, ni peuplés, ni bâtis, et la concentration des chutes, aboutiront à des coûts qui compenseront le coût du transport de l'électricité à longue distance. Les puissances disponibles sont en effet d'une importance telle qu'un barrage ne représente qu'un faible investissement par cheval.

La description détaillée de tous les aménagements hydroélectriques actuellement en service dans la Province de Québec nécessiterait probablement plusieurs volumes. Nous nous contenterons de donner quelques indications sur deux réalisations en cours d'achèvement : Beauharnois et Bersimis.

\section{IV}

\section{L'AMENAGEMENT DE BEAUHARNOIS}

L'aménagement de Beauharnois utilise les forces hydrauliques disponibles sur le fleuve SaintLaurent entre les lacs Saint-Francois et SaintLouis. Sur une distance d'environ $25 \mathrm{~km}$, trois séries de rapides produisent une dénivellation de $24 \mathrm{~m}$. Comme le débit du Saint-Laurent disponible $90 \%$ du temps en amont de Beauharnois est voisin de $5.660 \mathrm{~m}^{3} / \mathrm{s}$, la puissance permanente récupérable est d'environ $1.800 .000 \mathrm{ch}$. Ce débit est contrôlé à la sortie du lac Saint-François par quatre barrages s'appuyant sur trois îles (voir fig. 4). O'n peut ainsi diriger l'eau dans un canal d'une longueur de $24 \mathrm{~km}$ creusé sur la rive sud et à la sortie duquel l'eau retourne au lac SaintLouis après avoir subi une chute de $24 \mathrm{~m}$ à travers l'usine de Beauharnois. L'usine compte actuellement 26 turbines Francis d'une puissance totale de $1.400 .000 \mathrm{ch}$. En 1960, une fois la troisième étape de l'aménagement terminée, la Centrale de Beauharnois aura une capacité totale de $2.150 .000 \mathrm{ch}$ et produira 13 millions $500.000 \mathrm{kWh}$ par an. Une fois l'aménagement de Beauharnois terminé, la Centrale des Cèdres (voir fig. 4) sera maintenue pour les sur- atomic energy will be able to compete successfully with water power, even when the latter is located relatively far from consumption centers. It is therefore highly probable that the rivers of the North coast and those located near James Bay will be harnessed in the near future, inasmuch as these rivers are located close to important mining centers. These rivers are indeed far from Montreal, but their development can be particularly economical as shown by the striking example of the harnessing of the Bersimis river. The shape of the watersheds which can be easily enlarged by the acquisition of land neither cultivated nor inhabited, and the concentration of waterfalls of a power such that a dam requires a relatively small investment per horsepower, will result in costs compensating the cost of transmission networks.

A detailed description of all the hydroelectric developments of the Province of Quebec would require a few volumes. In this article, we shall therefore limit ourselves to a few indications on two important projects now being completed : Beauharnois and Bersimis.

\section{IV. - BEAUHARNOIS}

Beauharnois is located on the St. Lawrence River between Lake St. François and Lake St. Louis. In a distance of about 16 miles, a series of three rapids produce a drop of 80 feet. At Beauharnois, the flow of the St. Lawrenceavailable 90 p.c. of the time-is about $200,000 \mathrm{cfs}$ which makes available a permanent power of about 1,800,000 HP. The flow is controlled at the end of Lake St. Francois by four dams leaning upon three islands (see Figure 4). The flow can thus be directed in a canal 15 miles in length dug on the south bank and at the end of which water returns to Lake St. Louis after a drop of 80 feet across the Beauharnois powerplant. The powerplant is now equipped with 26 turbines of the Francis type giving a total power of $1,400,000 \mathrm{HP}$. The third stage of the development will be completed in 1960 bringing the total capacity to 2,150,000 $\mathrm{HP}$ and the plant will then have a yearly production of $13,500,000 \mathrm{kWh}$. The Cedres powerplant (see Figure 4) now using the water not absorbed by Beauharnois will be used for the peak hours and will also serve to handle the excess water not required by Beauharnois. 


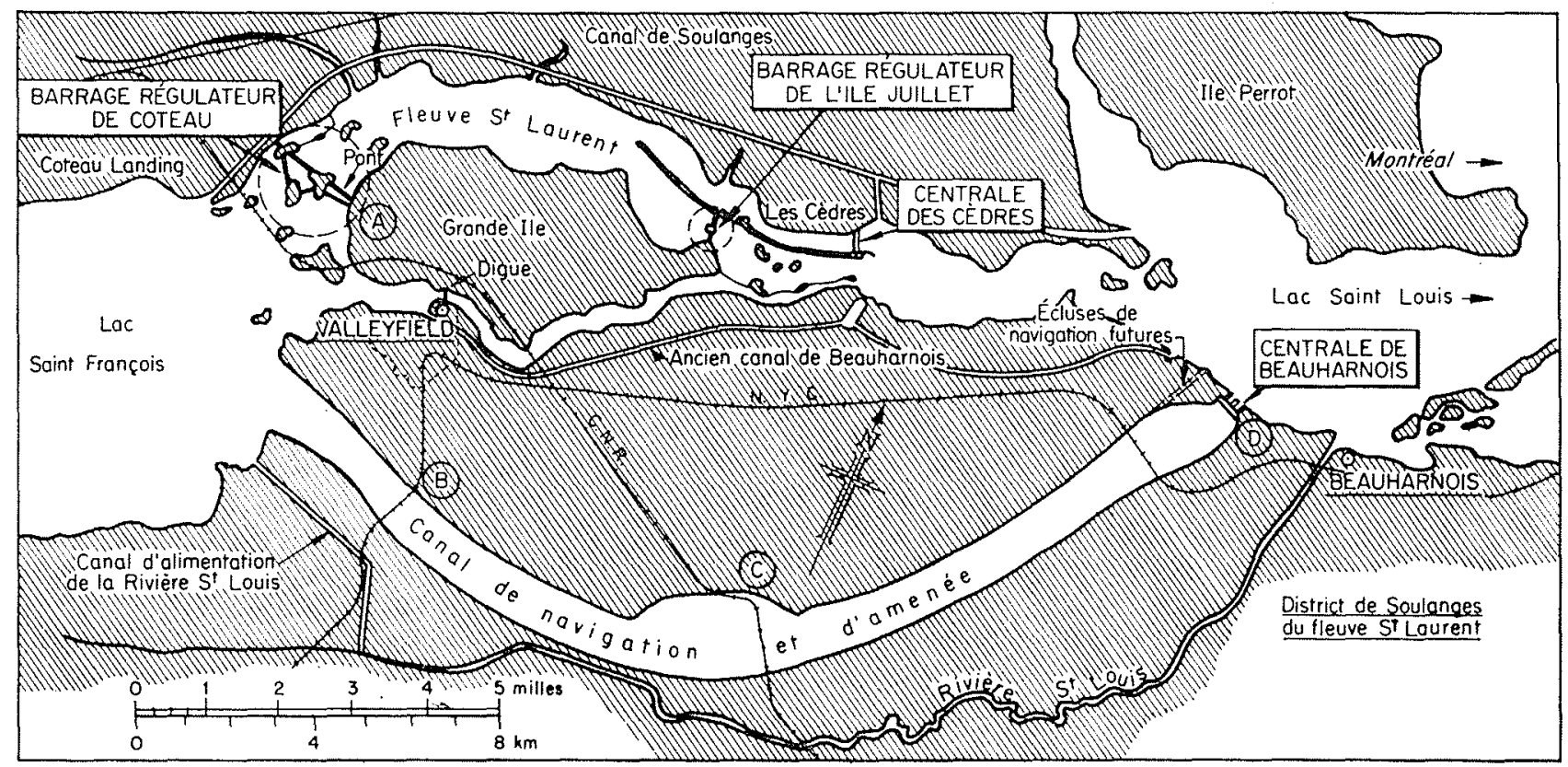

Fig. 4. - Aménagement de Beauharnots.

A. Le barrage régulateur de Coteau permet, à l'aide d'une digue et de trois barrages à pertuis, de maintenir le lac Saint-François à son niveau naturel.

$B$ et C. Pont-route et ferroviaire.

D. Centrale de Beauharnois.

Brauhariots.

A. The dyke and three regulation dams in the Cotean system enable late Saint-Francois to be maintained at its natural level.

$B$ and C. Road and rail bridge.

D. Beanharnois power station.

plus d'eau et probablement pour faire des pointes.

Le canal de Beauharnois présente des caractéristiques tout à fait remarquables. L'excavation de ce canal exige le déplacement de 180.000 .000 de $\mathbf{m}^{3}$ de matériaux. Notons en passant que ceci non seulement dépasse la quantité de matériaux à déplacer pour le reste de l'aménagement de la Voie Maritime du Saint-Laurent actuellement en construction, mais également l'excavation nécessitée pour construire le canal de Panama. Pour donner une idée de l'importance des travaux d'excavation, M. Dupuis fait observer que, si le canal était creusé avec pelles et camions, 200 camions de 2 tonnes, travaillant dix heures par jour sans arrêt pendant les douze mois de l'année, prendraient exactement cent ans pour enlever tous les déblais à excaver.

Le tracé du canal a été déterminé pour tirer le profit maximum des facilités de creusement en tenant compte des matériaux à enlever (A. Rousseau, 1957) : argile marine 130.000.000 $\mathrm{m}^{3}$, argile à blocaux $45.000 .000 \mathrm{~m}^{3}$ et roc $5.00 .000 \mathrm{~m}^{3}$. L'argile marine constituant environ $75 \%$ du volume de l'excavation, l'emploi des dragues hydrauliques à succion s'imposa. Deux dragues suceuses ont été utilisées : la drague « R.O. Sweezey », du nom du promoteur du projet
The Beauharnois canal has some highly remarkable characteristics. The excavation of this canal required the displacement of some $210,000,000$ cu.yd. of materials. For the sake of comparison let us indicate that this quantity is not only larger than the quantity of materials to be excavated for the remaining portion of the St. Lawrence Seaway but is also larger than the quantity of materials excavated for the construction of the whole Panama Canal. To give an idea of the importance of this work, Dr. Dupuis (1954), indicates that if the Beauharnois canal had been excavated with crane and trucks, it would have taken exactly 100 years for 200 two ton trucks to complete the job, assuming that these trucks worked without interruption 10 hours a day during the 12 months of the year.

The design of the canal took advantage of the particularly interesting dredging possibilities with respect to the texture of the material to be excavated : 183,000,000 cu.yd. of marine clay, $60,000,000$ cu.yd. of boulder clay, and 7,000,000 cu.yd. of rock (A. Rousseau, 1957). The choice of the suction-type hydraulic dredges was necessary because of the marine clay, the volume of which amounted to about 75 p.c. of the total volume to be excavated. Two suction-type dred- 
Beauharnois, et la drague «Hydro-Québec ». La drague «Sweezey » excave de 3 à 7 millions de $\mathrm{m}^{3}$ de matériaux par an, la production variant par suite de l'hétérogénéité des matériaux. Cette drague ne peut attaquer les banes d'argile trop durs et sa pompe n'est pas construite pour passer de trop grosses roches. En 1951, on fit construire la drague « Hydro-Québec » pour excaver l'argile à blocaux. L'étude et les appareils hydrauliques de cette drague, la plus puissante du monde, furent faits par la maison Ellicott de Baltimore, l'assemblage et la construction étant l'œuvre des usines Simard de Sorel.

Ses caractéristiques sont les suivantes : conduites d'aspiration de 42 pouces; conduite de re- ges are used; the dredge "R.O. Sweezey" (Mr. Sweezey was the promoter of the Beauharnois project), and the dredge "Hydro-Quebec." The Sweezey dredge excavates each year between 3 and 7 millions cu.yd. of materials, the volume varying because of the heterogeneity of the materials. The dredge cannot be used in the boulder clay and its pump was not designed to handle large stones. In 1951, the dredge "HydroQuebec " was designed and built for the excavation of the boulder clay. The design and the hydraulic machinery of this dredge was made by the Ellicott Company in Baltimore, while the assembling and construction was made by Simard of Sorel. The dredge is the largest suction

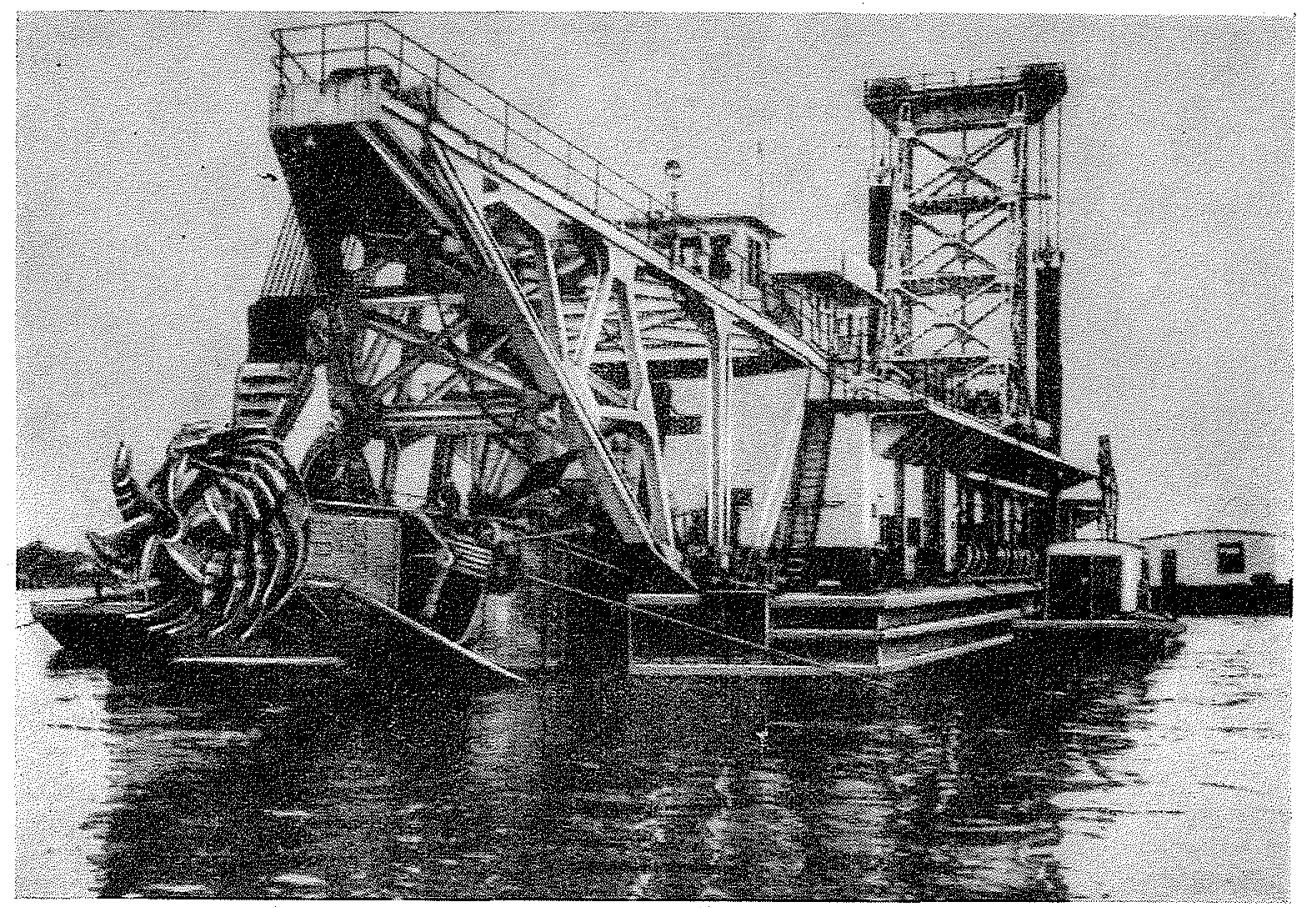

FIG. 5. - L' « Hydro-Québec », la plus grande drague à succion du monde, à l'ouvre dans le canal de Beauharnois.

The "Hydro-Quebec"- the largest suction dredge in the worldat work in the Beauharnois canal.

foulement 36 pouces; moteur de la pompe $8.000 \mathrm{ch}$; travail annuel 2 à 6 millions de $\mathrm{m}^{3}$. Cette drague est une merveille de construction, qui a attiré nombre de visiteurs de toutes les parties du monde. Malgré la mise de fonds considérable qu'elle a nécessitée, cette drague diminue de plusieurs millions de dollars le coût d'excavation de l'argile à blocaux.

Plusieurs dragues à benne preneuse sont utilisées pour ramasser les cailloux d'au-delà de 30 pouces, que la pompe de l'Hydro-Québec refuse de prendre; elles servent également à nettoyer le fond du canal. Indiquons que le canal est creusé de manière telle que la vitesse de dredge in the world. Its main characteristics are : 42 inches suction pipe; 36 inches discharge pipe; $8,000 \mathrm{HP}$ motor. The dredge excavates between 2.5 and 6 millions cu.yd. of materials each year. The construction of this dredge represents a wonderful accomplishment and visitors from all parts of the world have come to see it at work in the Beauharnois canal. In spite of its high initial cost, this dredge has reduced the cost of excavation of the boulder clay by a few million dollars.

A few bucket-type dredges are used to pick up boulders of more than 30 inches, and to clean up the bottom of the canal. The canal is ex- 


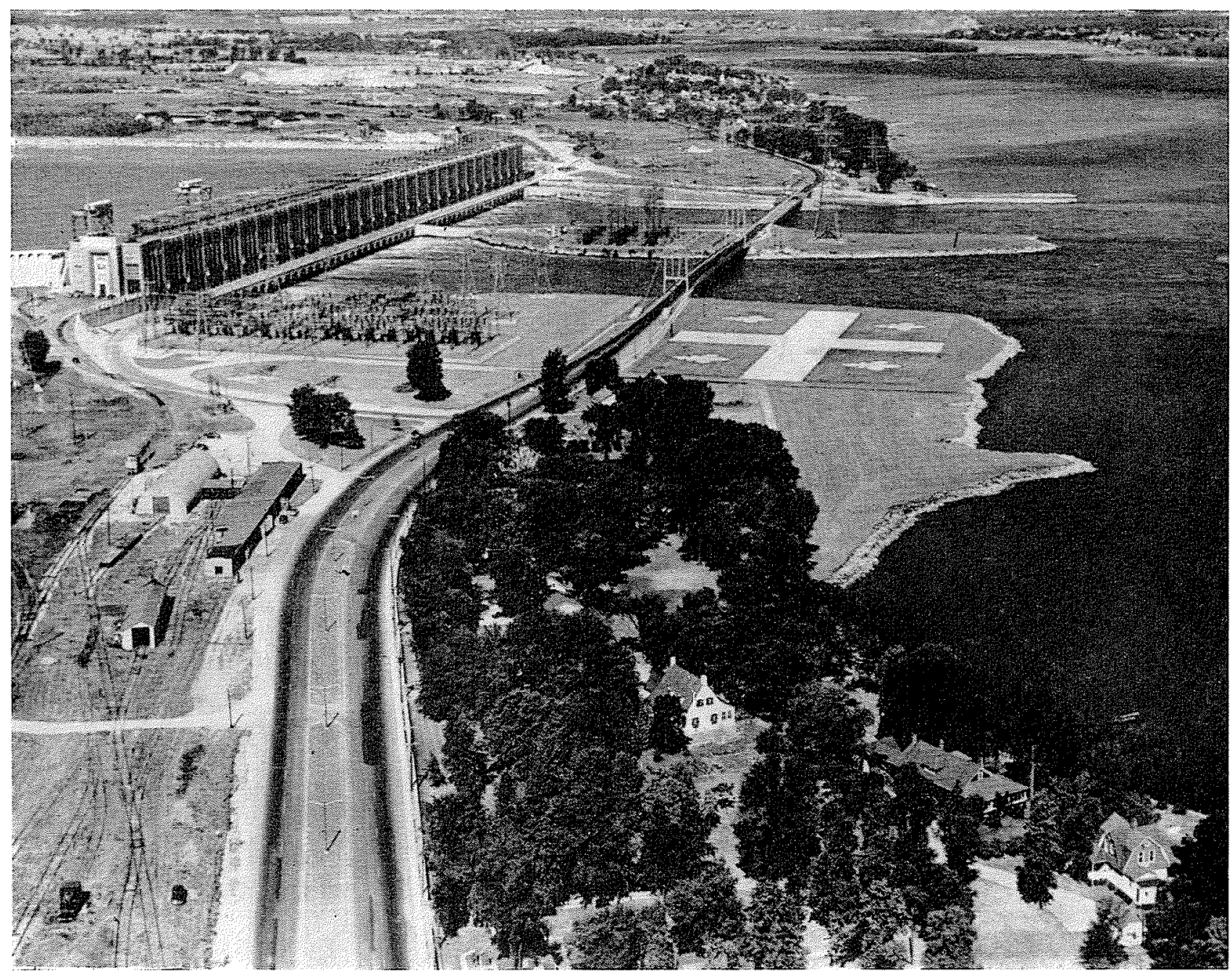

Fic, 6. - La centrale de Beauharnois.

Beauharnois power station.

l'eau, dans les conditions de charge maximum à l'usine, ne dépasse pas 2,25 pieds par seconde $(0,686 \mathrm{~m} / \mathrm{s})$. Cette vitesse permet la formation d'une couche solide de glace en surface durant l'hiver, èliminant ainsi la majeure partie des ennuis dus au «sorbet ». Le canal de Beauharnois non seulement dessert la centrale, mais il servira également à la navigation. En effet, tout a été prévu pour l'ouverture de la Voie Maritime du Saint-Laurent. Un chenal de $180 \mathrm{~m}$ de largeur et de $8,2 \mathrm{~m}$ de profondeur est préparé pour ces fins. Le canal de navigation se sépare du canal de Beauharnois à $1,6 \mathrm{~km}$ en amont de la centrale pour se trouver, en passant par deux écluses de $12 \mathrm{~m}$. de dénivelée, au niveau du lac SaintLouis.

N'ous terminerons cette brève description de l'aménagement de Beauharnois en rendant un hommage aux initiateurs du projet qui ont vu dès 1925 (Dupuis, 1951) : cavated to a depth such that the velocity of the water is always less than $2.25 \mathrm{ft} / \mathrm{sec}$. This relatively low velocity allows the formation of a sheet of ice during the winter, thus preventing the major part of the troubles due to frazil ice.

The canal is not only the life-line of the Beauharnois powerplant but, it will also serve navigation purposes. Included in its 3,300 foot width is a navigation channel 600 feet wide and 27 feet deep which will permit passage of oceangoing vessels. This navigation channel separates itself from the Beauharnois canal one mile upstream from the plant and joins Lake St. Louis after passing through two $40 \mathrm{ft}$. locks. This navigation channel is a part of the St. Lawrence Seaway under construction.

We shall conclude this brief description of the equipment of Beauharnois by paying homage to the promoters of the projects who, as early as 1925, realized : (Dupuis, 1951). 
1) Qu'il y avait une source d'énergie de 2.000.000 de ch entre le lac Saint-Francois et le lac Saint-Louis;

2) Que l'emplacement de la Centrale était à quelques kilomètres seulement de Montréal et que l'excès de courant produit pourrait se transporter à Toronto;

3) Que la topographie des lieux et la composition du sol se prêteraient au creusage par drague hydraulique, le seul économique;

4) Que le canal pourrait servir aux fins de navigation;

5) Qu'il y avait moyen de faire un aménagement progressif en trois stages où les capitaux ne seraient immobilisés qu'au moment où ils seraient productifs.

La figure 6 est une photo de la centrale de Beauharnois dans son état d'achèvement en 1955. On remarquera le drapeau de la Province avec les fleurs de lis.

\section{V. - L'AMENAGEMENT DE LA BERSIMIS}

Obligée de chercher de nouvelles sources d'énergie électrique, la Commission hydroélectrique de Québec a entrepris un projet à la fois gigantesque et hardi, celui de l'aménagement de la rivière Bersimis (appellation simplifiée de Betsiamites) pour metre à la portée de Montréal l'électricité venant des solitudes de la côte nord de Québec. Cet anénagement (voir fig. 7), dont une première tranche de $450.000 \mathrm{ch}$ a été achevée en 1956, est décrit en détail dans de nombreux

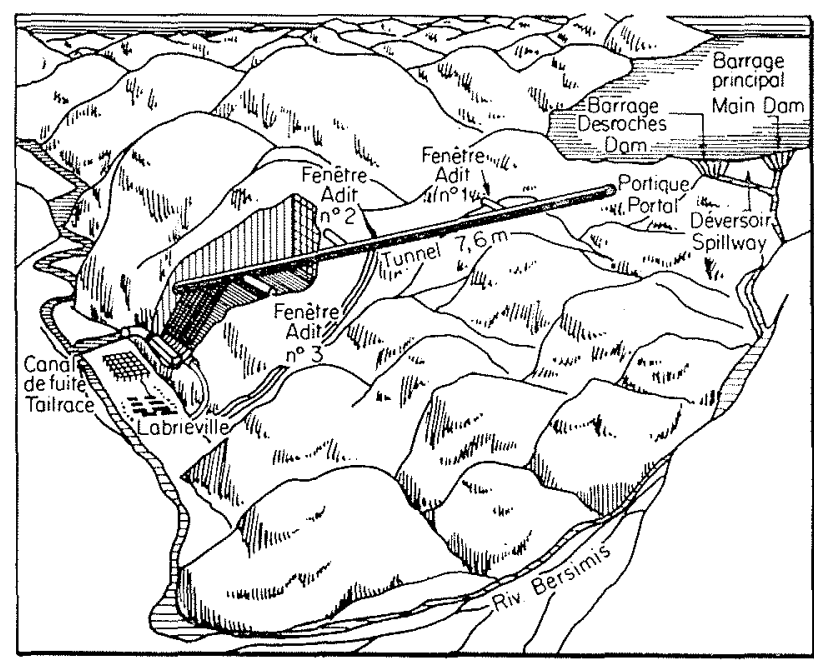

FIG. 7

Vue à yol d'oiseau de la région Lac Cassé-Labrieville, avec coupe longitudinale du tunnel et de la centrale.

Bird's elye view of the Lac Cassé-Labrieville area, with a longitudinal section of the tunnel and power house.
1. 'That there was a water power potential of 2,000,000 HP between Lake St. François and Lake St. Louis;

2. 'That the location of the powerplant would be only a few miles from Montreal and that the excess of energy could be easily exported towards Toronto;

3. That the topography and the texture of the soil would permit an economic excavation by hydraulic dredging;

4. That the canal could be used for navigation purposes;

5. That the development could be completed in three stages thus requiring successive investments in accordance with the demand for power.

Figure 6 represents a photo of the Beauharnois powerplant in 1955. One shall notice the flag of the Province with the "fleurs de lis".

\section{$V$ - THE BERSIMIS HYDROELECTRIC DEVELOPMENT}

It was in 1952 that the Quebec Hydro-Electric Commission decided to go ahead with the $1,200,000 \mathrm{HP}$ Bersimis-lac Casse development to meet the rapidly increasing demand for power to supply the ever-growing industries in the Province of Quebec (Perryman, 1957). The many difficulties and challenge that such an undertaking presented have been successfully met, and the Bersimis power development is justly considered as an outstanding engineering achievement.

A first stage $(450,000 \mathrm{HP})$ of this development was completed in 1956 and the problems encountered are described in many articles (Dupuis, 1954; Forest, 1956; F. Rousseau, 1956; Perryman, 1957). We shall limit ourselves to a few characteristics of this project (see Figure 7). We already have mentioned that the Bersimis River with its narrow steep rocky banks, provide favorable sites for power plants. The most important potential head on the river-amounting to approximately $720 \mathrm{ft}$-is formed by a series of falls and rapids over a stretch of about 20 miles below Lake Casse. With a drainage area of 4,500 square miles and high banks, Lake Pipmuacan provides the most favorable storage conditions. Cost studies (Rousseau, 1957) established that the most economic utilization of the river could be realized : 1 ) by building two 
articles (Dupuis, 1954; Forest, 1956; F. Rousseau, 1956; Perryman, 1957).

Nous nous contenterons ici de donner les caractéristiques générales de ce projet. Nous avons déjà indiqué au début de cet article que la rivière Bersimis se prête admirablement à l'aménagement de forces hydrauliques. Un barrage au lac Cassé retiendra dans les lacs Cassé et Pipmuacan quelque 10 milliards de $m^{\prime 3}$ d'eau dont 4,4 milliards utilisables entre les cotes 388 et $396 \mathrm{~m}$ provenant des $12.500 \mathrm{~km}^{2}$ du bassin versant supérieur de la rivière. Pour tirer profit des chutes échelonnées dans les $29 \mathrm{~km}$ en aval du barrage, un tunnel bétonné de $12,2 \mathrm{~km}$ de longueur et de $9,6 \mathrm{~m}$ de diamètre les contournera pour alimenter la centrale souterraine située à Labrieville. La hauteur de chute utilisée sera de $267 \mathrm{~m}$, avec un débit régularisé à l'année de $264 \mathrm{~m}^{3} / \mathrm{s}$ pour produire au-delà d'un million de chevaux.

A Labrieville, le tunnel se terminera par 8 conduites d'amenée, chacune d'elles alimentant un groupe générateur à turbine Francis de $150.000 \mathrm{ch}$ sous une chute de $239 \mathrm{~m}-176.000$ ch sous la chute maximum de $267 \mathrm{~m}$, - soit une installation totale de $1.200 .000 \mathrm{ch}$. Ces groupes, comprenant quatre turbines Neyrpic et quatre turbines English Electric, seront parmi les plus puissants groupes hydroélectriques qui existent.

Une trentaine de kilomètres plus bas, une autre centrale (Bersimis II) d'une puissance totale de $800.000 \mathrm{ch}$ est en construction. Cette centrale arrachera à la rivière le reste de sa puissance hydraulique.

Indiquons pour terminer que l'aménagement de la Bersimis, situé à quelque $450 \mathrm{~km}$ de Québec, a nécessité la mise en cuvre de moyens considérables. Les moyens d'accès à Labrieville sont limités. La principale voie de transport est évidemment l'eau, mais pendant l'été seulement, et, par suite, l'avion joue un rôle très important. Une route de $135 \mathrm{~km}$ de long a été construite pour relier Forestville à Labrieville. Il a également fallu ouvrir $50 \mathrm{~km}$ de route pour relier les différentes parties du chantier. Une petite ville, Labrieville, a été créée, avec paroisse, école, hòpital, hôtel, central téléphonique, centre commercial et administratif, centre récréatif, etc. La disposition de la ville et tous les détails de ses constructions ont été l'objet d'études poussées de la part d'architectes. Qu'il suffise ici d'indiquer que la porte d'entrée principale de chacune des maisons s'ouvre sur un parc.

C'est à juste titre que la Commission hydroélectrique de la Province peut être fière de cet aménagement, d'autant plus que les installations successives se présentent à l'exploitation aux moments prévus et tout le projet, malgré les difficultés de sa réalisation, se maintient au coût que les premières estimations ont déterminé. rock-fill dams at the outlets of Lake Casse to impound the water at elevation 1,300 , and 2 ) by tapping the storage by means of a 7,5 mile tunnel ( 31 feet in diameter) of section sufficient to carry the flow of 13,250 c.f.s. for maximum utilization of the river at 70 p.c. load factor. This tumnel, driven across the bend formed by the river, would terminate by 8 penstocks feeding 8 Francis turbines housed in an underground powerhouse at Labrieville. These turbines are rated at $150,000 \mathrm{HP}$ under a $785 \mathrm{ft}$. head176,000 under the maximum head of $875 \mathrm{ft}$. bringing the total capacity to $1,200,000 \mathrm{HP}$. These generating units which include 4 Neyrpic turbines and 4 English Electric turbines are among the most powerful hydroelectric groups in the world.

The Bersimis River undergoes another drop of 370 feet in a 20 mile stretch downstream from Labrieville. A powerplant (Bersimis II) is now under construction to harness the remaining $800,000 \mathrm{HP}$ of the river.

We shall conclude this very short description of the Bersimis River development by mentioning an outstanding aspect which makes this development different from the average hydroelectric project. Consideration had to be taken of the unique requirement of an entirely isolated country to establish a group of well organized communities in the heart of a forest, 300 miles from Quebec City. A road connecting Labrieville and Forestville had to be constructed in order to accommodate the transport of the heavy equipment to the construction sites. A special dock at Forestville had to be built to cater for the ships bringing in machinery and materials although during the Winter months air transportation played a very important part. A permanent townsite of far larger proportion than usual was founded at the powerhouse site, and will eventually accommodate the operating staff. There are now 116 houses pleasantly laid out in a semi-circle near the bank of the Bersimis with spacious parks between the rows.

"Hydro-Quebec" can be justly proud of this power development inasmuch as despite the difficulties common to a monumental task of this nature, the project is being realized according to the original estimates of financial expenditure. 


\section{CONCLUSIONS}

Ce n'est pas à tort que l'on a surnommé la Province de Québec «la terre de l'avenir». Elle connaît aujourd'hui un essor prodigieux sous l'impulsion d'hommes clairvoyants qui osent rêver de grandes choses et les réaliser. Grâce à l'exploitation sur une grande échelle de ses ressources naturelles, grâce à l'essor d'une industrie déjà prospère, grâce à l'apport de nouveaux capitaux, l'industrie hydroélectrique de la Province de Québec a joué et jouera encore un rôle de première importance.

Qu'il nous suffise ici, à titre d'exemple, de donner les noms de quelques aménagements actuellement en voie de réalisation. Les plus importants sont ceux de l' «Hydro-Québec » avec Beauharnois $(2.150 .000 \mathrm{ch})$, Bersimis I (1.200.000 ch), Bersimis II avec cinq grempes de $171.000 \mathrm{ch}$ qui fonctionneront dès 1959 , Lachine I (1.000.000 de ch) dont la construction commencera vraisemblablement en 1959, tandis que Lachine II, avec ses $450.000 \mathrm{ch}$, ne sera démarré que beaucoup plus tard.

L'Aluminum Company of Canada poursuit la construction d'une centrale souterraine de 1.000 .000 de ch à la Chute-des-Passes, sur la rivière Péribonka, à $460 \mathrm{~km}$ au nord de la ville de Québec. L'eau arrivera à la centrale par un tunnel de près de $10 \mathrm{~km}$ de long, terminé par une chute de $210 \mathrm{~m}$. La centrale sera équipée de cinc groupes générateurs ayant chacun une puissance de $200.000 \mathrm{ch}$ (Civil Engineering, 1957). La production d'aluminium nécessite de grandes quantités d'énergie et la Province de Québec produit chaque année plus de 540.000 tonnes d'aluminium, soit le $1 / 8^{\circ}$ de la production totale d'Amérique du Nord.

Indiquons enfin que la Shawinigan Water and Power Company a commencé la construction d'une centrale de $350.000 \mathrm{ch}$ aux Rapides de Beaumont sur la rivière Saint-Maurice.

Nous terminerons cet article en souhaitant que la puissance électrique soit utilisée de plus en plus par des industries employant le plus grand nombre possible d'individus.

\section{REMERCIEMENTS}

L'auteur tient à exprimer ses très vifs remerciements au $D^{r}$ René Dupuis, commissaire de

\section{CONCLUSIONS}

Quebec seems to have been rightly named "the land of the future" The Province knows today an amazing industrial growth under the leadership of clear-sighted men who dare dream great projects and realize them. Thanks to the development to a large scale of its natural resources, thanks to the rapid progress of an already prosperous industry, and thanks to the subscription of capital, the hydroelectric industry of Quebec has played, and shall continue to play, a leading part in the welfare of the Province.

This part can perhaps be better shown by mentioning a few of the most important hydroelectric developments now under construction. The Quebec Hydro-Electric Commission is the leader with the development of Beauharnois $(2,150,000 \mathrm{HP})$, Bersimis I $(1,200,000 \mathrm{HP})$, Bersimis II $(800,000 \mathrm{HP})$ which will be completed in 1959, and Lachine I $(1,000,000 \mathrm{HP})$ the construction of which will probably start in 1959

The Aluminum Company of Canada Ltd. is now building a $1,000,000 \mathrm{HP}$ underground powerhouse at Chute-des-Passes on the Peribonka River, about 300 miles North of Quebec City. This project involves digging a six-mile tunnel which will carry a flow of 18,000 efs from a storage lake to a point where the water will drop almost $636 \mathrm{ft}$. vertically to the powerhouse. This powerhouse will have five generators of 200,000 HP capacity each (Civil Engineering, 1957). The production of aluminum requires large quantities of energy (some $24,000 \mathrm{kWh}$ per ton of product) and Quebec has an annual capacity of over 540,000 tons, or nearly oneeight of the total capacity in North America (Huet Massue, 1956).

Another important hydroelectric development now under construction in Quebec, is the harnessing of $330,000 \mathrm{HP}$ at Rapide Beaumont on the St. Maurice River. This powerplant is built by the Shawinigan Water and Power Company.

Important additional sources of low cost hydroelectric power will continue to attract industries to Quebec. It is very important however, for the greatest benefit of the whole population, that an increasing part of that power be directed to industries employing the greatest possible number of people.

\section{ACKNOWLEDGMENTS}

The author wishes to express his deep appreciation to Dr. René Dupuis, commissioner of the 
l' «Hydro-Québec», qui a bien voulu lui donner de précieux conseils et lui communiquer une importante documentation. Sa reconnaissance va enfin au regretté Professeur A. Jorissen, de l'Université Cornell, qui avait bien voulu relire le manuscrit.
- Quebec Hydro-Electric Commission whose suggestions and information have proved most useful. Thanks are also due to late Professor André Jorissen of Cornell University for reviewing the manuscript.

\section{BIBLIOGRAPHIE}

* Aluminium Company Builds Underground Powerhouse in Quebec "; Civil Engineering, October 1957, p. 108.

Dupuis (R.). « La Aménagement de Beauharnois »; 1951 (rapport non publié).

Duprrs (R.) : «L'Aménagement de la Bersimis »; L'Ingénieur (revue trimestrielle canadienne), automne 1954.

Forest (C) : « Les harrages et les tunnels d'amenée à Bersimis »; L'Ingénieur, automne 1956.

Heartz (R. E.) : «L'équipement du Saint-Maurice 》; $L a$ Houlle Blanche, janvier 1951.

Hyıno-Québec : « Beauharnois 》 (1951).

Hydro-Québec : « Dix ans de progrès »: 1944-1954 (1954).

Hydro-QúkBec : "Bersimis 》 (1956).

Lawton (F.) : « Hydro-Electric Power Development in Quebec »; Technical paper 47-124 (1947), American Institute of Electrical Engineer.

Massue (H.) : « Hydroelectric Porwer in Ouebec » (1956)

Montague (J.R.) : « Engineering Aspects of the Ottawa River Power Development $\gg ;$ The Engineering Journal, vol. 33, No $10(1950)$, pp. 850-863. Résumé par P. CARLe, La Houille Blanche, numéro spécial A-1951, pp. 329-330.
Nonmandin (A.): « Undevelopped Water Powers in the Province of Quebec $\gg$; paper delivered at the 67 th Annual Meeting of the Engineering Institute of $\mathrm{Ca}$ nada, at Quebec, May 12, 1949.

Perryman (O.): «The Bersimis-Lac Casse Scheme»; Water Power, June 1957.

Prévost (E.) : « La centrale provisoire pour le projet hydroélectrique de la rivière Bersimis »; L'Ingénieur, automne 1956 .

Rousseau (F.) : « Bersimis-Lac Casse Hydroelectric Power Development s; The Engineering Journal, April 1956.

Rousseau (A.) : « Le canal de Beauharnois »; L'Ingénienr, été 1957 .

Department of Northern Aftairs and National Resources, Water Resources Branch, Annual Review, 1957 , «Water-Power resources of Canada».

Fox (A.) : « Chute des Passes, Construction Drama 》, Engineering News Record, 14 novembre 1957, pp. 5255 .

«Hydro-Quebec finishes first and pushes second Bersimis River job 》, Engineering News Record, 19, décembre 1957 , pp. $28-32$.

C'est avec une douloureuse sympathie que nous avons appris, tout récemment, le brusque décès de M. HENRI HUPNER, Inspecteur Général des Ponts et Chaussées.

A travers la Socièté Hydrotechnique de France, dont il fut un brillant Président, et an sein de laquelle il déployait, avec un inlassable dévouement, toutes les ressources de sa maîtrise subtile et souriante, l'Inspecteur Général Hupner avait bien voulu nous honorer de son amitié, et, en maintes circonstances, nous prodiguer ses conseils et ses encouragements.

Dans un très prochain numèro, nous comptons consacrer $\dot{a}$ sa mémoire la place d'honneur qui lui est due; mais nous ne voulons pas tarder davantage pour exprimer ici, à sa famille, à la Société Hydrotechnique de France, à ses collaborateurs, à ses innombrables amis, nos sentiments de profonde sympathie. 